\title{
Isolation and Characterization of a Colonic Autoantigen Specifically Recognized by Colon Tissue-bound Immunoglobulin G from Idiopathic Ulcerative Colitis
}

Fumio Takahashi and Kiron M. Das

Division of Gastroenterology and Liver Disease, Department of Medicine, Albert Einstein College of Medicine, Bronx, New York 10461

\begin{abstract}
Patients with idiopathic ulcerative colitis (UC) have a colonbound antibody (CCA-IgG) that reacts with colon tissue extracts. We have partially characterized a colonic protein that is specifically recognized by CCA-IgG. CCA-IgG was eluted from operative colon specimens from 10 patients with UC. A colon tissue-bound IgG was similarly eluted from six patients with Crohn's colitis, two with ischemic colitis, and one with diverticulitis. Purified serum IgG from patients with Crohn's disease, from normal subjects and a patient with myeloma were also used as additional controls. For detection of antigen(s), tissue extracts were prepared from 26 specimens of colon (UC, 12; Crohn's disease, 6; normal, 4; other controls, 4), 8 specimens of human normal stomach, duodenum, ileum, and liver (2 each). Tissue extracts were also prepared from rats and mice, including germ-free rat colons and rat's fetal colons. Immunorecognition of CCA-IgG to the tissue extracts was examined by affinity-column chromatography and by transblot analysis. Tissue-extracted proteins were electrophoresed in SDS-polyacrylamide gel, transferred to nitrocellulose sheet, and probed with iodinated CCA-IgG, colonic IgG from other inflammatory bowel disease patients, UC serum IgG, and control serum IgG. Although many proteins were present in colon tissue extracts, 9 of $10 \mathrm{CCA}-\mathrm{IgG}$ consistently recognized a protein of $40 \mathrm{kD}$. None of the nine IgG preparations from colon specimens of patients with Crohn's colitis and other colonic inflammatory diseases reacted with the $40-\mathrm{kD}$ protein. Five of six symptomatic UC serum IgG and none of eight control serum IgG reacted with the $40-\mathrm{kD}$ protein. The $40-\mathrm{kD}$ protein was present in all colon specimens and it appeared to be organ specific. It was absent in mouse and rat tissues, including colon. The $40-\mathrm{kD}$ protein is not actin and nor a part of the Ig molecule. These results suggest that the $40-\mathrm{kD}$ protein is a colonic "autoantigen" that may initiate a specific IgG antibody response in $\mathrm{UC}$.
\end{abstract}

\section{Introduction}

Despite extensive research, the pathogenesis of ulcerative colitis (UC) $^{1}$ is unclear. Among allergic, dietary, infectious, and

This work was presented in part at the 85th Annual Meeting of the American Gastroenterological Association, New Orleans, 21 May, 1984, and published in abstract form in 1984. Gastroenterology. 86: 1057.

Address reprint requests to Dr. Das.

Received for publication 18 July 1984 and in revised form 19 February 1985.

1. Abbreviations used in this paper: CCA, colon tissue-bound antibodies in patients with idiopathic ulcerative colitis; IEF, isoelectric focusing;

J. Clin. Invest.

(C) The American Society for Clinical Investigation, Inc. 0021-9738/85/07/0311/08 \$1.00

Volume 76, July 1985, 311-318 immunologic mechanisms, autoimmunity has been emphasized (1), although the nature of the antigen and antibody interaction is unknown. Clinical findings, such as family history of frequent atopic diseases and association with autoimmune hemolytic anemia, thrombocytopenic purpura, and systemic lupus erythematosus (2), suggest autoimmune involvement. Circulating heterogeneous antibodies against various alimentary tract antigens, such as intestinal bacterial polysaccharide, antigen(s) from germ-free rat feces, and rat colonic epithelial glycoproteins $(1,3,4)$, have been demonstrated. Circulating immune complexes (5) and immune complexes in situ were demonstrated in patients with UC (6), and IgG immunocytes are increased in the lamina propria in UC (7). We previously described colon tissue-bound antibodies in patients with UC and termed it CCA. In indirect immunofluorescence assay, CCA bound to colonic epithelium from patients with UC (8). Purified CCAIgG preferentially bound to colon extracts in vitro when compared with control IgG (9). In the present studies, we eluted colon bound IgG from additional patients with UC and other inflammatory colonic diseases and demonstrated that CCA-IgG and not other colon eluted IgG or normal serum IgG specifically reacts with a colonic "autoantigen(s)." This antigen has been partially characterized, and its organ and species specificity have been examined.

\section{Methods}

\section{Human specimens}

Operative specimens of colon were obtained from 22 patients, including 12 patients with ulcerative colitis, 6 patients with Crohn's colitis, 2 patients with ischemic colitis, and 2 with diverticulitis. Histologically normal segments of colon were obtained during colonic carcinoma resection from six additional patients with colon carcinoma. Specimens of histologically normal tissues, including ileum, duodenum, stomach, and liver (two each) were obtained from eight patients who underwent abdominal surgery for various reasons. Tissues were received within half an hour of surgery, separated from serosal fat, washed with phosphate-buffered saline (PBS) (10 mM sodium phosphate, $0.15 \mathrm{M}$ sodium chloride, $\mathrm{pH} 7.5$ ) and stored at $-80^{\circ} \mathrm{C}$ in $10 \mathrm{~g}$ aliquots. The study was approved by the Human Experimentation Committee of the Albert Einstein College of Medicine.

10 of 12 patients with UC were operated on due to refractoriness to medical treatment, and in 2 patients, early toxic megacolon were suspected before surgery. All patients were treated with corticosteroid either orally or by intravenous administration and sulfasalazine immediately before surgery. All patients with UC had extensive colitis extending up to right colon. Three of six patients with Crohn's colitis had involvement of transverse and descending colon, two had ileocolitis with involvement of ascending colon and one had segmental colitis involving the sigmoid colon only. All six patients were treated with sulfasalazine and four received corticosteroids as well. Of the two patients with ischemic colitis, one had involvement of the entire colon

pI, isoelectric point; PMSF, phenylmethylsulfonyl fluoride; SDS-PAGE, sodium dodecyl sulfate-polyacrylamide gel electrophoresis; UC, idiopathic ulcerative colitis. 
and the other patient had left hemicolectomy with involvement of splenic flexure area. Diverticulitis was localized in the sigmoid colon in both patients. Grossly diseased areas were used for these studies.

\section{Rat and mouse specimens}

Six healthy Wistar rats and $10(\mathrm{nu} /+)$ BALB/c mice were decapitated and specimens of stomach, liver, and the small and large intestine were dissected and stored at $-80^{\circ} \mathrm{C}$. Similar specimens were obtained from four $\mathrm{nu} /+$ rats that were inbred and kept in germ-free isolators. 10 rat fetuses were obtained by sectioning the uterus of two full-term pregnant rats. The colon specimens from fetuses obtained from each mother were pooled and used for extraction of tissue proteins.

\section{Extraction and purification of CCA-IgG}

CCA-IgG was extracted and purified as described earlier (8) with slight modifications. A total of 22 colon specimens were used for extraction of tissue bound IgG. These included 10 patients with UC, 6 with Crohn's colitis, 2 with ischemic colitis, 1 with diverticulitis, and 3 normal colons. Each colon specimen was minced, homogenized, and washed extensively with $0.01 \mathrm{M}$ phosphate buffer with $0.15 \mathrm{M} \mathrm{NaCl}$ (PBS), pH 7.2, containing $2 \mathrm{mM}$ phenylmethylsulfonyl fluoride (PMSF), $2 \mathrm{mM}$ EDTA, and $2 \mathrm{mM}$ sodium azide. The final wash was concentrated 1,000-fold and examined for immunoglobulin. Tissue-bound Ig was eluted in acid buffer using $0.02 \mathrm{M}$ citrate, $\mathrm{pH} 3.2$, and $0.1 \mathrm{M}$ glycine$\mathrm{HCl}, \mathrm{pH} 2.8$. The acid eluate was dialyzed against PBS until the $\mathrm{pH}$ was adjusted to 7.2 and concentrated by a diaflow membrane (pM 10; Amicon Corp., Scientific Sys. Div., Danvers, MA). IgG was purified by protein A coupled to Sepharose 4B. Purified IgG was examined by double diffusion in agar and sodium dodecyl sulfate polyacrylamide gel electrophoresis (SDS-PAGE) (10) and quantitated by radial immunodiffusion.

\section{Purification of serum IgG.}

Serum immunoglobulin $\mathrm{G}$ (IgG) from six patients with symptomatic UC and five patients with active Crohn's disease and three control subjects were purified by ammonium sulfate precipitation followed by DEAE-52 column chromatography (11) and examined by double immunodiffusion, immunoelectrophoresis, and by SDS-PAGE (10).

\section{Extraction of tissue proteins}

Each tissue specimen was thawed, minced into small pieces, washed five times in 5 vol of PBS, pH 7.2, containing $2 \mathrm{mM}$ PMSF and 2 $\mathrm{mM}$ sodium azide. After centifugation at $1,000 \mathrm{~g}$ for $5 \mathrm{~min}$, the tissue pellet was homogenized in the same buffer including $1 \mathrm{mM}$ EDTA ( 5 vol [wt/vol]) on ice in a Polytron (Kinematic type PT 1020350D; Switzerland) at $5 \times$ speed for four 10-s intervals (9). Homogenates were centrifuged at $2,000 \mathrm{~g}$ for $20 \mathrm{~min}$ to remove large tissue particles and ultracentrifuged at $20,000 \mathrm{~g}$ for $60 \mathrm{~min}$ to obtain a clear supernatant. The protein concentration in the supernatants was adjusted to 5-10 $\mathrm{mg} / \mathrm{ml}$ and were stored with $10 \%$ glycerol at $-80^{\circ} \mathrm{C}$ in $2-\mathrm{ml}$ aliquots. The same procedure was performed for organs obtained from rats and mice. Before each experiment, the extracts were thawed and centrifuged at $20,000 \mathrm{~g}$ for $60 \mathrm{~min}$ to remove aggregates.

\section{Affinity column chromatography to examine immune recognition of eluted colon tissue-bound IgG to tissue antigen(s)}

Using protein-A Sepharose CL-4B bound to IgG. $200 \mu \mathrm{l}$ of washed, hydrated protein-A Sepharose CL-4B (Pharmacia Fine Chemicals, Inc., Piscataway, NJ) in PBS was incubated with 1-2 mg of CCA-IgG and control normal serum IgG. The gel was washed three times with PBS. Tissue extracts containing 5-10 mg of protein were passed slowly through the column. The gel was washed with 10 bed volumes of PBS. Proteins bound to the protein-A Sepharose CL-4B were eluted in 3 bed volumes of $0.02 \mathrm{M}$ citrate buffer, $\mathrm{pH}$ 3.2. The resulting protein solution was neutralized with $0.1 \mathrm{M} \mathrm{NaOH}$ to $\mathrm{pH} 7.0$ and lyophilized.

Using IgG coupled with cyanogen bromide-activated Sepharose $4 B$. Colon-eluted IgG and control serum IgG were coupled to Sepharose
4B in the ratio of $4 \mathrm{mg} / \mathrm{ml}$ of gel. Gels were equilibrated with $0.01 \mathrm{M}$ PBS, pH 7.2. To remove nonspecific binding proteins, 0.5 to $1 \mathrm{ml}$ of tissue extract in PBS/PMSF containing $5-10 \mathrm{mg}$ of protein was incubated with myeloma IgG coupled Sepharose 4B (2 ml) overnight at $4^{\circ} \mathrm{C}$ in a side-to-side rotor. The gel was centrifuged at $1,000 \mathrm{~g}$ for $15 \mathrm{~min}$ and the supernatant was gently passed through small columns (100-200 $\mu$ l) control serum IgG followed by CCA-IgG coupled Sepharose 4B. The gel was washed five times in 0.01 M PBS, pH 7.2. Bound proteins were eluted in three times the gel volume of $2 \mathrm{M}$ potassium thiocyanate in PBS ( $\mathrm{pH}$ 7.4), dialyzed against $0.05 \mathrm{M} \mathrm{NH}_{4} \mathrm{HCO}_{3}$ and concentrated.

Identification of affinity chromatography-prepared proteins. Proteins were electrophoresed in $7.5 \%$ and $10 \%$ SDS-PAGE. Gels were stained with $0.02 \%$ Coomassie Brilliant Blue. $50 \mu \mathrm{g}$ of protein from each eluate was iodinated with ${ }^{125} \mathrm{I}-\mathrm{Na}$ using the iodogen method (12). lodinated proteins were separated from free iodine by Sephadex G-25 column chromatography, reduced in $5 \% \beta$-mercaptoethanol and analyzed by SDS-PAGE. The gels were subjected to autoradiography using a high-speed intensifying screen (Picker Corp., Highland Heights, $\mathrm{OH}$ ).

Transblot assay to examine immune recognition of eluted colon tissue bound IgG to tissue antigen(s)

The assay was performed as described by Towbin et al. (13) with slight modifications. Briefly, equal amounts of tissue extracts were electrophoresed in SDS-PAGE (10\%) and transferred to nitrocellulose sheet at $30 \mathrm{~V}$ over $16 \mathrm{~h}$. To block nonspecific binding sites, the nitrocellulose sheet was incubated with $5 \%$ bovine serum albumin in $0.05 \mathrm{M}$ Tris$\mathrm{HCl}$ containing $0.15 \mathrm{M} \mathrm{NaCl}, \mathrm{pH} 7.9$, for $2 \mathrm{~h}$ at room temperature. In paired experiments, the nitrocellulose sheet containing transferred proteins was divided into two parts, each contains identical tissue extracts. The nitrocellulose strips were directly probed with iodinated CCA-IgG and control IgG. $50 \mu$ g of purified IgG (e.g., CCA-IgG and tissue eluated IgG from Crohn's or ischemic colitis) was iodinated by the iodogen method (12) as described above. Each strip was incubated with $10 \mathrm{ml}$ of ${ }^{125} \mathrm{I}-\mathrm{IgG}$ containing $3 \times 10^{5} \mathrm{cpm} / \mathrm{ml}$ counts for $2 \mathrm{~h}$ at room temperature with constant gentle stirring. The strips were washed once with Tris-saline buffer, $\mathrm{pH} 7.9$, containing $0.1 \%$ Triton X-100 and twice with Tris-saline buffer without Triton X-100, dried, and subjected to autoradiography. In the indirect method, strips were incubated with equal amounts of cold $\mathrm{IgG}$ for $2 \mathrm{~h}$ at room temperature followed by $10 \mathrm{ml}$ of ${ }^{125}$ I-protein A $\left(3 \times 10^{5} \mathrm{cpm} / \mathrm{ml}\right)$ for $30 \mathrm{~min}$. To ensure persistance of immunoreactivity of iodinated IgG, we electrophoresed anti-human IgG in parallel to the tissue extracts.

\section{Transblot assay to examine immune recognition of serum IgG to tissue antigen(s)}

For these experiments, PBS colon extracted proteins were partially purified by the use of DEAE cellulose ion exchange chromatography (11) with discontinuous $\mathrm{KCl}$ salt gradient. This semipurification step was necessary to reduce nonspecific bindings of serum IgG to several colon-extracted proteins. 10-15 mg of PBS extracted colonic tissue proteins were passed through a DEAE cellulose column (6-ml bed volume) equilibrated with potassium phosphate (pH 7.4) buffer. Proteins were eluted with 2 bed volumes of different concentrations of $\mathrm{KCl}$ such as $0.025,0.05,0.1,0.2,0.25,0.3,0.35$, and $0.5 \mathrm{M}$. Eluted proteins were dialyzed, electrophoresed on SDS polyacrylimide gel, electroblotted to nitrocellulose sheets, and incubated with ${ }^{125} \mathrm{I}-\mathrm{CCA}-\mathrm{IgG}$ and ${ }^{125} \mathrm{I}$ serum IgG from patients with UC, Crohn's disease of colon with or without ileal involvement, and normal subjects. The strips were washed as mentioned above and subjected to autoradiography.

\section{Two-dimensional gel electrophoresis}

Human colon extract $(100 \mu \mathrm{g} / 50 \mu \mathrm{l})$ was diluted with 2 vol of $8 \mathrm{M}$ urea, 2\% (wt/vol) Nonidet P-40, 2\% Ampholines (1.6\%, pH 5.7, and 0.4\%, pH 3-10 [Sigma Chemical Co., St. Louis, MO]), 5\% $\beta$-mercaptoethanol, $10 \%$ glycerol and incubated for $30 \mathrm{~min}$ on an isoelectric focusing (IEF) gel prepared as described by Leaback and Rutter (14). The focused IEF gel was incubated for $1-2 \mathrm{~h}$ in an equilibration buffer 
Table I. Isolation of Colon Tissue-bound IgG

from Patients with Inflammatory Bowel Diseases

\begin{tabular}{lll}
\hline Patients & $\begin{array}{l}\text { Number of } \\
\text { specimens }\end{array}$ & $\begin{array}{l}\text { Purified colon tissue-bound } \\
\text { IgG }\end{array}$ \\
\hline & & $\mu g / g$ wet tissue (mean \pm SEM) \\
Ulcerative colitis & 10 & $74.2 \pm 19.6^{*}$ \\
$\begin{array}{l}\text { Crohn's disease } \\
\text { Ischemic colitis and }\end{array}$ & 6 & $15.2 \pm 3.9$ \\
$\quad$ diverticulitis & 3 & $9.0 \pm 2.9$ \\
Normals & 3 & $3.3 \pm 1.1$ \\
\hline
\end{tabular}

${ }^{*} P<0.05$.

consisting of $0.0625 \mathrm{M}$ Tris- $\mathrm{HCl}, \mathrm{pH} 6.8,10 \%$ glycerol (wt/vol), $5 \%$ $\beta$-mercaptoethanol, 2.3\% SDS. After incubation, the IEF gel was fixed to a $10 \%$ SDS-PAGE and run in the second dimension as described by O'Farrell (15). The SDS-PAGE resolved sample was then transfered to nitrocellulose sheet by transblot analysis (13) and the antigen was localized by incubation with ${ }^{125} \mathrm{I}-\mathrm{CCA}-\mathrm{IgG}$ as described above.

\section{Results}

Table I summarizes the yield of tissue-bound purified IgG from colon specimens of patients with UC, Crohn's colitis, ischemic colitis, diverticulitis, and normal colon. The amount of tissue bound IgG was highest in UC specimens with a mean of $74.2 \mu \mathrm{g} / \mathrm{g}$ wet tissue when compared with Crohn's disease colon of $15.2 \mu \mathrm{g} / \mathrm{g}$ of wet tissue and ischemic colitis and diverticulitis of $9.0 \mu \mathrm{g} / \mathrm{g}$ of wet tissue. The yield of CCA-IgG was significantly $(P<0.05)$ higher in UC compared with the tissue-eluted IgG from Crohn's disease and other control tissue specimens (Table I). Tissue-bound IgG was barely detectable in the normal colon. Crude CCA contained mostly IgG, and minute amounts of $\operatorname{IgA}$, albumin, and traces of other unidentified proteins. Protein A-Sepharose 4B removed all IgG present in the crude acid eluate (Fig. 1, and Fig. $2 a$, lanes 1 and 2).

The immune recognition of CCA-IgG was initially examined by affinity chromatography. After elution of CCA-IgG, the residual tissue pellet was rehomogenized in PBS with $0.1 \%$ Triton X-100 and the extracted proteins were passed through the CCA-IgG bound protein-A column. The bound proteins were eluted by citrate buffer at pH 3.2 and were examined by SDS-PAGE as shown in Fig. $2 a$. Crude CCA (Fig. 2a, lane 1) contained several proteins, including albumin, heavy and light chains of IgG which was separated by protein-A column (Fig. $2 a$, lane 2). Fig. $2 a$, lane 4 was the acid eluate and it contained $\mathrm{CCA}-\mathrm{IgG}$ and an additional $40-\mathrm{kD}$ protein. This suggests that the residual tissue pellet from which CCA-IgG was eluted contained an extractable $40-\mathrm{kD}$ protein(s) which bound to CCA-IgG. Control serum IgG bound to the protein A column did not recognize the $40-\mathrm{kD}$ protein.

The recognition of the $40-\mathrm{kD}$ protein by CCA-IgG was also demonstrated in additional immunoabsorbant column experiments using cyanogen bromide-activated Sepharose 4B coupled to CCA-IgG and control IgG (Fig. $2 b$ ). The acid eluates following passage of colon extracts were iodinated, electrophoresed in SDS polyacrylimide gel and autoradiographed and they contained $\mathrm{Ig}$, albumin, and the $40-\mathrm{kD}$ protein (Fig. $2 \mathrm{~b}$ ). The $40-\mathrm{kD}$ protein was present in normal colon extract (Fig. $2 b$, lane 1 ) and in the autologous extract of the UC colon specimen (Fig. $2 b$, lane 2), a part of which was used for extraction of CCA-IgG.

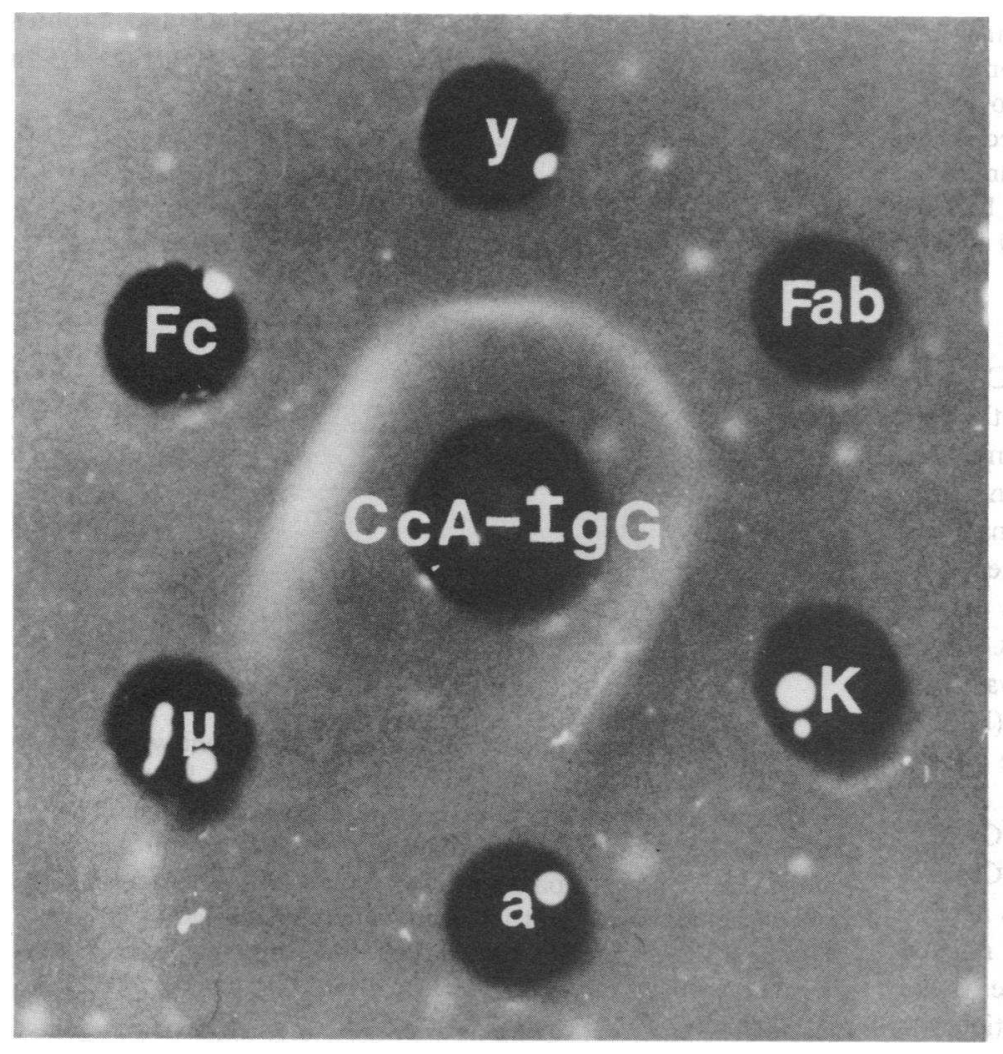

Figure 1. Double immunodiffusion in agar. Protein-A purified CCA-IgG is at the central well. Peripheral wells contain antisera to $\gamma$ (designated by $\mathrm{Y}$ ), $\alpha$ (designated by a), $\mathrm{K}$, and $\mu$ chains, and Fab and Fc fragments of IgG. 

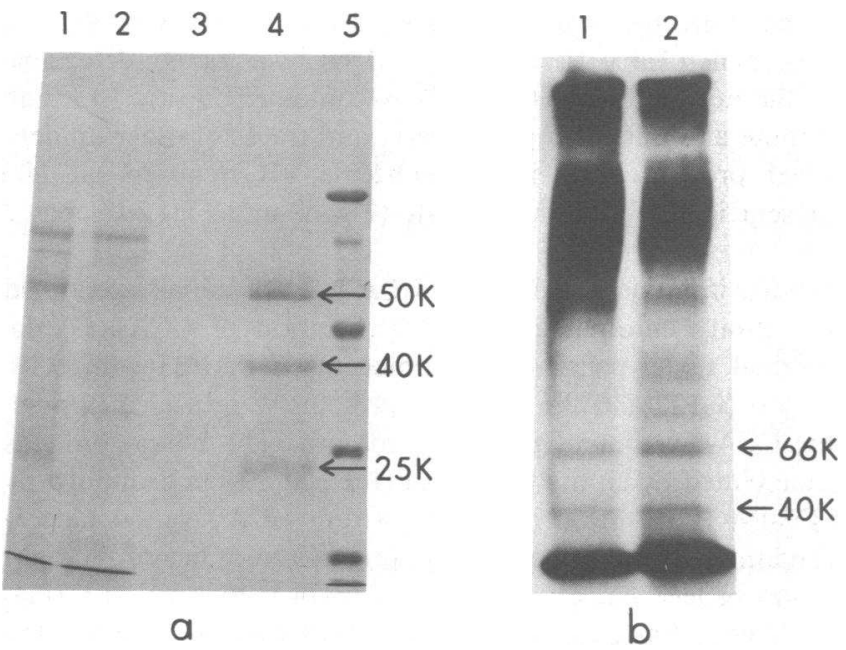

Figure 2. Affinity chromatography to examine immune recognition of CCA-IgG to colonic extracts. (a) $0.02 \%$ Coomassie Brilliant Blue staining of the SDS-PAGE (10\%). All samples were reduced with $5 \%$ $\beta$-mercaptoethanol. Crude CCA (lane 1) contained albumin and heavy and light chains of IgG. IgG was almost completely separated by Protein-A column (lane 2 and Fig. 1). PBS wash of the Protein-A column (lane 2) after passage of crude CCA contained mostly albumin and traces of heavy and light chains. To examine whether CCAIgG binds with any protein(s) in the residual UC colon tissue pellet following extraction of CCA-IgG, we further homogenized the pellet in PBS containing $0.1 \%$ Triton $\mathrm{X}-100$ and passed extracted proteins through the CCA-IgG bound Protein-A column. Lane 4 contained the acid (pH 3.2) eluate that demonstrates heavy and light chains of CCA-IgG as expected and an additional protein of $40 \mathrm{kd}$. Lane 3 contained concentrated final PBS wash of CCA-IgG bound Protein-A column after passage of the pellet extract showing no residual unbound protein. Lane 5 contained marker proteins that are included from above downwards 92-, 66-, 45-, 31-, and 14-kD proteins. $\mathrm{K}$, $\times 1000$. (b) Autoradiogram of SDS-PAGE (7.5\%) of proteins eluted by $2 \mathrm{M}$ potassium thiocyanate from CCA-IgG coupled to cyanogen bromide activated Sepharose 4B columns following incubation of normal colon (lane 1 ) and UC colon (lane 2) extracts. The bound proteins were iodinated, electrophoresed and autoradiographed. The eluted proteins contained from above downwards large amount of Ig, albumin $(66 \mathrm{~K})$, and also the distinct band of $40-\mathrm{kD}$ protein. The 40 $\mathrm{kD}$ protein was present in both normal colon extract (lane 1) and the autologous colon extract (lane 2).

To examine the specific binding protein(s) with CCA-IgG, we subsequently used more sensitive and direct method of transblot analysis, in which very small amounts of colon eluted IgG were needed. In Fig. 3, the extreme right hand lane demonstrates transferred colon-extracted total proteins from SDS-PAGE to the nitrocellulose sheet that was stained with Coomassie Brilliant Blue. There are many proteins in the colon extract with a wide range of molecular weights. When probed with ${ }^{125} \mathrm{I}-\mathrm{CCA}-\mathrm{IgG}$, only one band at $40-\mathrm{kD}$ was seen; no bands were seen with control normal serum IgG (Fig. 3). Both UC and normal colon extracts contained the 40-kD protein(s) specifically recognized by CCA-IgG.

In separate experiments, equal amounts of both CCA-IgG and colon tissue-bound IgG eluted from patients with Crohn's colitis or ischemic colitis were used in transblot assays against the same extracts of colon from patients with UC and normal controls. Because of the small amount of eluatable tissue bound IgG in patients with ischemic colitis and diverticulitis,

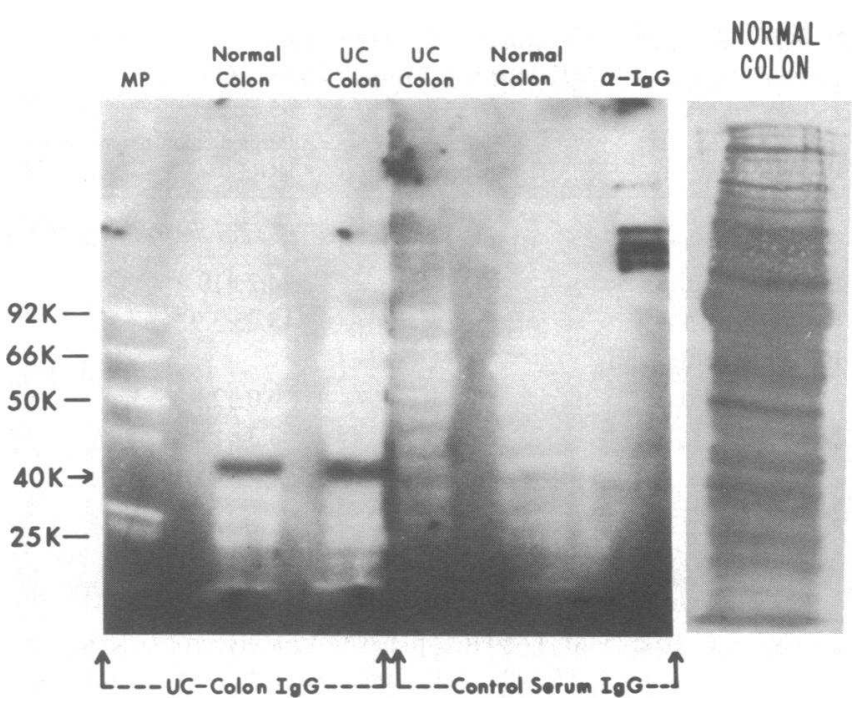

Figure 3. An autoradiogram from transblot experiment in which a normal and a UC colon extracts were probed with ${ }^{125} \mathrm{I}-\mathrm{CCA}$-IgG (UC-colon-IgG) and ${ }^{125}$ I control human serum IgG. The extreme right lane shows the Coomassie Blue-stained nitrocellulose sheet strip containing transferred proteins from a normal colon extract. Of all the transferred proteins only one protein of $40-\mathrm{kD}$ reacted with the CCA-IgG. This protein was present in both colon extracts. No recognition was found with control serum IgG. MP, marker proteins. Also note that ${ }^{125}$ I-control serum IgG was recognized by anti-human IgG $(\alpha$-IgG). K, $\times 1,000$.

purified IgG from these specimens was pooled and used for transblot experiments. Fig. 4 demonstrates that CCA-IgG recognized the $40-\mathrm{kD}$ protein in two UC colon extracts, whereas tissue-eluted IgG from Crohn's colitis did not react to this protein, further demonstrating the disease specificity of CCA-lgG. Iodinated samples of both CCA-IgG and Crohn's tissue eluted IgG reacted with anti-human IgG (Fig. 4). In

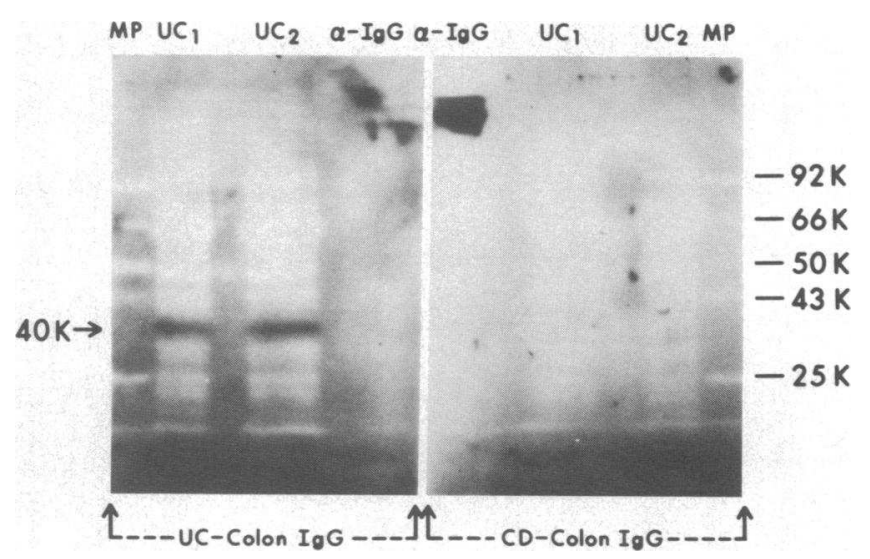

Figure 4. An autoradiogram from transblot experiment where two UC colon extracts (UC1 and UC2) were probed with ${ }^{125}$ I-CCA-IgG (UC-colon IgG) and Crohn's disease colon tissue eluted IgG (CDcolon IgG). CCA-IgG reacted only with the $40-\mathrm{kD}$ protein that was present in both UC colon extracts. CD-colon IgG did not react with any of the transferred proteins. Anti-human IgG $(\alpha-\operatorname{lgG})$ reacted with both CCA-IgG and CD-colon IgG, indicating the persistence of immunoreactivity following radioiodination. MP, marker protein; $K$, $\times 1,000$. 
similar experiments, tissue-eluted IgG from Crohn's colitis did not react with the $40-\mathrm{kD}$ protein in colon extracts from Crohn's colitis and normal colon. The recognition of this 40$\mathrm{kD}$ protein(s) by CCA-IgG was demonstrated with 9 of the 10 CCA-IgG preparations and none of the 9 control tissue eluted IgG nor with serum IgG or myeloma IgG.

To determine whether the $40-\mathrm{kD}$ protein is present in other human tissues, we probed extracts of normal ileum, duodenum, stomach, and liver with ${ }^{125} \mathrm{I}-\mathrm{CCA}-\mathrm{IgG}$ and control serum IgG. The $40-\mathrm{kD}$ protein was not detected by CCA-IgG in any of these tissues, except colon (Fig. 5). Control IgG did not react with any extract, including colon. One of the colon extracts was from the autologous colon (Fig. 5) from which the CCA-IgG was extracted. The $40-\mathrm{kD}$ protein was present in this autologous colon extract. Similar results were obtained with three additional patients with UC.

To examine species specificity, we performed experiments using extracts of tissue from conventional rats and rats inbred and kept in germ-free conditions and mice that included colon, small intestine, stomach, and liver. Extracts of colon specimens from rat fetus were also used. There were many protein bands in the $40-\mathrm{kD}$ area, as seen by Coomassie Blue staining of the nitrocellulose sheet. However, CCA-IgG did not react with any of the tissue extracts (Fig. 6). Fig. 6 demonstrates a paired experiment in which rat tissue extracts and human tissue extracts were probed with the same ${ }^{125}$ I-CCA-IgG. Although the $40-\mathrm{kD}$ proteins were detected by ${ }^{125} \mathrm{I}-\mathrm{CCA}-\mathrm{IgG}$ in the human colon extracts, it was not seen in all rat tissue extracts, including the colon. One human tissue extract was obtained from the ileocecal area, which was grossly normal. This patient had a right hemicolectomy for carcinoma of the ascending colon. Although ileal tissue extract did not react with CCAIgG, extract from the ileocecal area reacted (Fig. 5).

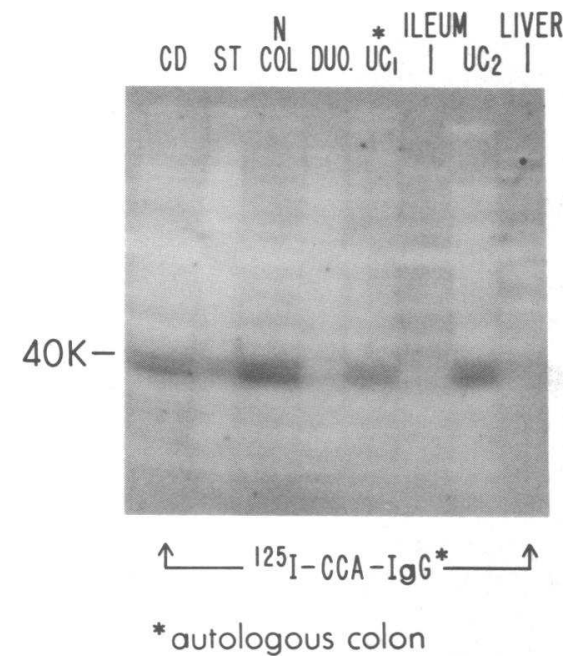

Figure 5. An autoradiogram from transblot experiment in which extracts of four colon specimens, one from Crohn's disease (CD), one normal colon (N. Col.), and two UC colons $\left(\mathrm{UC}_{1}\right.$ and $\left.\mathrm{UC}_{2}\right)$ were electrophoresed and transferred to nitrocellulose sheet. In addition, extracts of histologically normal human stomach (ST), duodenum (DUO), ileum, and liver were electrophoresed. All extracts were probed with ${ }^{125} \mathrm{I}-\mathrm{CCA}-\mathrm{IgG}$. The $40-\mathrm{kD}$ protein(s) were detected in all colon extracts. Extracts of stomach, duodenum, ileum, and liver did not react with the CCA-IgG. ${ }^{125}$ I-CCA-IgG reacted with the autologous colon extract as indicated in the figure. $\mathrm{K}, \times 1,000$.

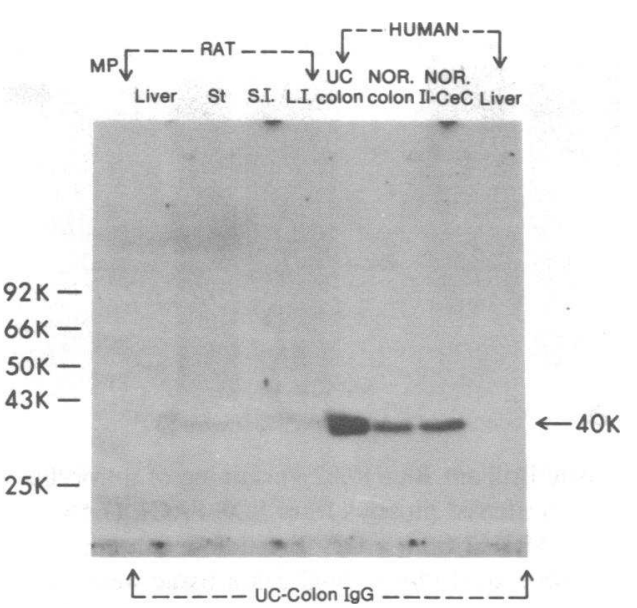

Figure 6. An autoradiogram from transblot experiment in which human tissue extracts and rat tissue extracts prepared from liver, stomach (ST), small intestine (S.I.), and large intestine (L.I.) were probed with ${ }^{125} \mathrm{I}-\mathrm{CCA}-\mathrm{IgG}$ (UC-colon IgG). All human colon extracts, including UC, normal (Nor.) colon, and normal ileocecal (Nor. IL$\mathrm{CeC}$ ) area, contained the $40-\mathrm{kD}$ protein as detected by CCA-IgG. Neither the human liver nor any of the rat tissue extracts reacted with the CCA-IgG. MP, marker protein; K, $\times 1,000$.

To determine the immunoreactivity of the $40-\mathrm{kD}$ protein with serum IgG, we purified serum IgG from six patients with symptomatic UC, five patients with active Crohn's disease involving colon with or without ileal involvement, and three normal subjects. Initial immunotransblot experiments using serum IgG and colon tissue extracted proteins caused significant high background due to nonspecific bindings of several proteins with serum IgG from all subjects. To reduce this nonspecific binding, we developed a method for purification and enrichment of the $40-\mathrm{kD}$ protein by ion exchange chromatography with discontinuous $\mathrm{KCl}$ salt gradients. Proteins eluted with $0.35 \mathrm{M}$ $\mathrm{KCl}$ contained enriched $40-\mathrm{kD}$ protein as detected by CCAIgG (Fig. 7). Subsequently, $0.35 \mathrm{M} \mathrm{KCl}$ eluated proteins were used to examine the immune recognition by each of 14 purified serum IgG (Fig. 7). Five of six patients with symptomatic UC reacted with the $40-\mathrm{kD}$ protein by immunotransblot analysis; no immune recognition was observed by serum IgG from five patients with symptomatic Crohn's disease and three normal subjects.

To examine the homogeneity and determine the isoelectric point (pI) value of the $40-\mathrm{kD}$ protein, we performed twodimensional SDS-PAGE followed by immunoblot studies, as shown in Fig. 8. The sample resolved by IEF demonstrated a major band of $40-\mathrm{kD}$ size immunoreactive to CCA-IgG at $\mathrm{pH}$ 5.8 and two minor components of the same molecular weight with more acidic pI.

To examine whether the $40-\mathrm{kD}$ protein is a part of the immunoglobulin molecule, we performed experiments using both affinity column chromatography and transblot system. An UC colon extract was sequentially passed through affinity columns prepared with purified serum IgG, anti-human IgG, IgA, and IgM (IgG fraction; Cappel Laboratories, Cochranville, PA) coupled with cyanogen bromide-activated Sepharose 4B. The PBS eluates containing unbound proteins and the 2-M potassium thiocyanate eluates from these columns containing the bound proteins were examined by transblot assays using 

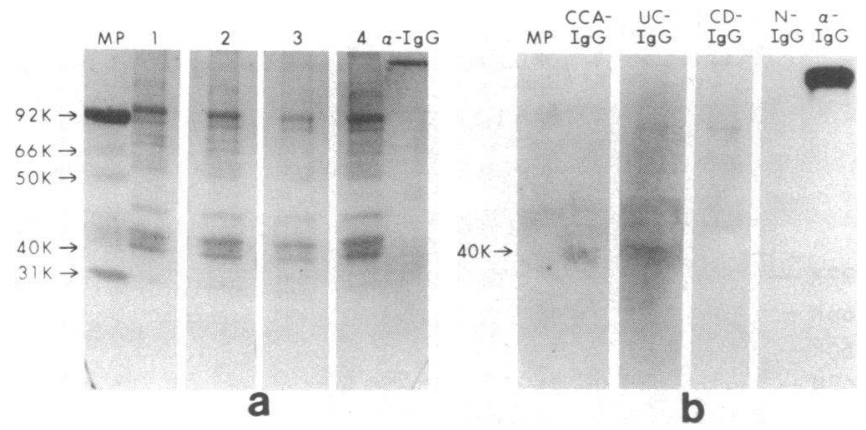

Figure 7. (a) Coomassie Brilliant Blue $(0.02 \%)$ staining of nitrocellulose strips containing transferred proteins from SDS-PAGE (7.5\%).

Proteins eluted by $0.35 \mathrm{M} \mathrm{KCl}$ from a DEAE cellulose column following passage of PBS extract of a normal colon tissue were electrophoresed in lanes 1-4. All lanes contained $80 \mu \mathrm{g}$ of total proteins isolated from the same colon tissue. MP stands for marker proteins and $\alpha$-IgG contained anti-human IgG. The $40-\mathrm{kD}$ protein(s) is enriched and a limited number of proteins, compared with PBS colon extract (Fig. 3, extreme right lane), can be seen in the $0.35 \mathrm{M}$ $\mathrm{KCl}$ eluates. (b) Autoradiogram from transblot experiment after the same nitrocellulose strips as in $a$ were incubated with radioiodinated CCA-IgG, serum IgG from a symptomatic patient with UC (UCIgG), an active Crohn's disease patient (CD-IgG), and serum IgG from a normal subject. The $40-\mathrm{kD}$ protein reacted with the CCA-IgG and also with UC serum IgG. Neither CD-IgG nor normal serum IgG reacted with the $40-\mathrm{kD}$ protein. There were some other nonspecific faint bands that were common to UC and control serum IgG. $\mathrm{K}, \times 1,000$.

${ }^{125} \mathrm{I}-\mathrm{CCA}-\mathrm{IgG}$. The $40-\mathrm{kD}$ protein was present in all PBS eluates (Fig. 9) and did not bind to any of the column(s). In separate transblot experiments, colon-extracted proteins were probed with radioiodinated anti-human IgG, IgA, and IgM. Although there was recognition of $\operatorname{IgG}, \operatorname{IgA}$, and $\operatorname{IgM}$, respectively, in the colon extracts, no reaction was noted with the $40-\mathrm{kD}$ protein. These results suggest that the $40-\mathrm{kD}$ protein is not derived from an Ig molecule.

Since actin is $43 \mathrm{kD}$ and colon tissue contains actin, we examined whether the $40-\mathrm{kD}$ protein could be actin and if CCA-IgG is directed to actin. Fig. 10 demonstrates an autoradiogram from a transblot experiment after incubation of a

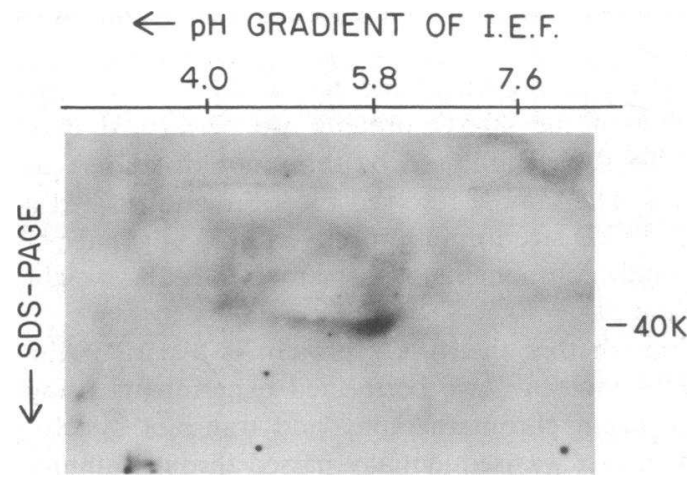

Figure 8. An autoradiogram of a two-dimensional gel in which the proteins were first separated by IEF at a $\mathrm{pH}$ range of 3-10 followed by $10 \%$ SDS-PAGE; proteins were transferred by transblot experiments and probed with ${ }^{125} \mathrm{I}-\mathrm{CCA}-\mathrm{IgG}$. A major band of $40-\mathrm{kD}$ at $\mathrm{pH}$ 5.8 and two minor components of the same molecular weight with slightly more acidic $\mathrm{pI}$ reacted with the CCA-IgG. K, $\times 1,000$.

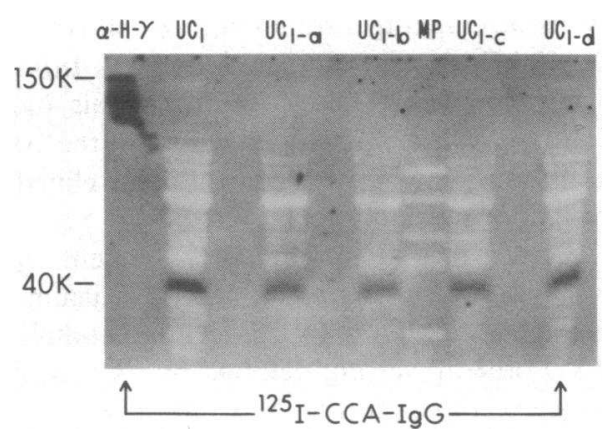

Figure 9. An autoradiogram from transblot experiment following incubation of ${ }^{125} \mathrm{I}-\mathrm{CCA}-\mathrm{IgG}$ with transferred proteins of a UC colon extract. Passed sequentially through affinity columns prepared with purified serum IgG and anti-human IgG, IgA, and IgM coupled to cyanogen bromide-activated Sepharose 4B. The PBS eluates containing unbound proteins were probed with ${ }^{125} \mathrm{I}-\mathrm{CCA}-\mathrm{IgG}$. The $40-\mathrm{kD}$ protein was present in all the eluates including the original UC extract. These results suggest that the $40-\mathrm{kD}$ protein is not a part of Ig. $\mathrm{UC}_{1}$, original UC colon extract; $\mathrm{UC}_{1 \mathrm{a}}, \mathrm{PBS}$ eluate from serum IgG coupled Sepharose 4B column; $U_{1 b}$, PBS eluate from antihuman IgG coupled Sepharose 4B column; $U_{\mathrm{lc}}$, PBS eluate from anti-human IgA coupled Sepharose 4B column; $U_{1 d}$, PBS eluate from anti-human IgM coupled Sepharose 4B column; MP, marker proteins; $\alpha-\mathrm{H}-\gamma$, antisera against human $\gamma$-chain. $\mathrm{K}, \times 1,000$.

UC colon extract, pure chicken actin (Sigma Chemical Co.) and human fibroblast extract with ${ }^{125} \mathrm{I}-\mathrm{CCA}-\mathrm{IgG}$ and antiactin antibody. CCA-IgG, although recognizing the $40-\mathrm{kD}$ protein,

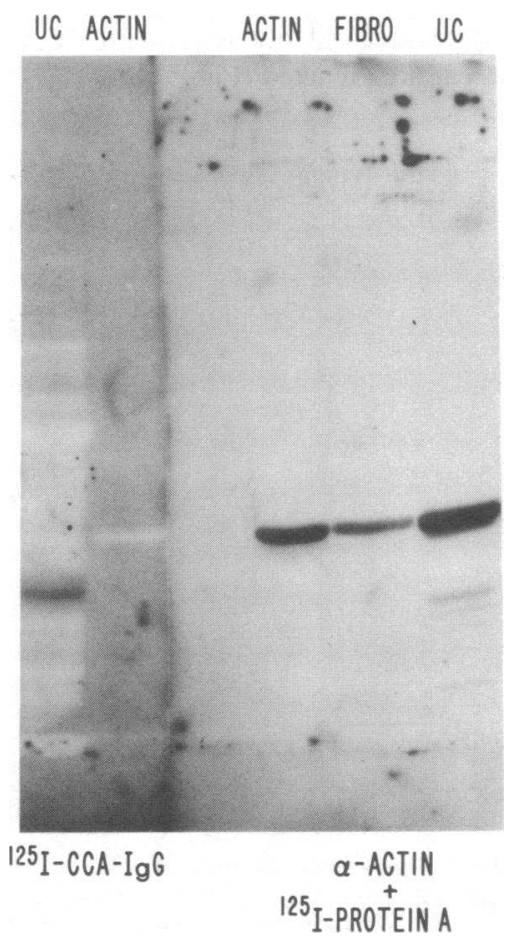

Figure 10. An autoradiogram from transblot experiment in which a UC colon extract (UC), pure actin, and human fibroblast extract (fibro) were probed with ${ }^{125} \mathrm{I}-\mathrm{CCA}-\mathrm{IgG}$ (on the left) and cold antiactin followed by ${ }^{125}$ I-Protein A (on the right). CCA-IgG reacted with the $40-\mathrm{kD}$ protein in the colon extract but not with actin. Antiactin reacted with pure actin and actin present in fibroblast and UC colon extract. 
did not react with actin that was recognized by antiactin. Antiactin reacted with actin present in the fibroblast extract and the UC extract.

\section{Discussion}

These studies confirm demonstration $(8,9)$ of a colon tissuebound IgG antibody in patients with $\mathrm{UC}$, which we termed CCA-IgG. Using affinity-column chromatography and transblot, we demonstrated that CCA-IgG recognizes a colon tissuespecific $40-\mathrm{kD}$ protein(s). This reactivity was specific for CCAIgG and was absent with colon tissue-eluted IgG from patients with Crohn's disease and ischemic colitis and purified serum IgG from healthy subjects and a myeloma patient. Furthermore, anti-human IgG, IgA, and IgM also did not react with the 40$\mathrm{kD}$ protein.

In previous experiments $(8,9)$, we did not detect tissuebound IgG in colon from patients with Crohn's colitis and normal patients (colon cancer patients). With improved methods and using several protease inhibitors, we increased the yield of elutable colon tissue-bound IgG in UC, and isolated small amounts of tissue-bound IgG from colon specimens of patients with Crohn's colitis, ischemic colitis, and diverticulitis. However, tissue-bound IgG is significantly $(P<0.05)$ higher in patients with UC than in patients with Crohn's colitis or ischemic colitis (Table I). Tissue-bound IgG in normal controls was nil or a trace amount that was not sufficient to perform further studies.

In previous studies using an indirect immunofluorescence assay (8) and radioimmunoprecipitation method (9), we demonstrated preferential recognition of UC colon tissue extract by CCA-IgG as compared with control IgG and control colon tissue. Using direct and more sensitive transblot experiments, we confirmed the disease specificity of CCA-IgG compared with several control IgG preparations, including colon tissueeluted IgG. A striking finding is the unique recognition of a possibly single (or multiple with close molecular weights) 40$\mathrm{kD}$ protein among many proteins present in colon extracts. In contrast to our previous reports, CCA-IgG recognized the 40$\mathrm{kD}$ protein in diseased and normal colon extracts probably due to increased sensitivity of the current assay. The other possibility is that in the indirect immunofluorescence assay used earlier, the "antigen(s)" in normal colon tissue is not "exposed" to be detected by CCA-IgG, whereas in patients with UC it is exposed. Whether there is any difference in the quantity of the $40-\mathrm{kD}$ protein in different colon tissue is unknown. Further studies of purification of the $40-\mathrm{kD}$ protein and its quantitation may answer this issue. If it is not exposed in normal tissue, it will be important to study what factors are involved in triggering antigenicity.

Circulating heterogeneous antibodies against various alimentary tract antigens, components of intestinal bacteria, e.g., Escherichia coli 0:14 polysaccharide, antigen(s) from germfree rat feces, and rat colonic epithelial glycoproteins, have been demonstrated in UC and in Crohn's disease (3, 4, 1619). These antibodies belonged to IgG, IgA, and IgM classes (19). The colon antigen from rats is a heat-stable polysaccharide, located in the mucus-producing cells of the colonic mucosa and in the mucus (20). Various epithelial cell-associated components from murine small intestine, but not from kidneys, have been found to cross-react with sera from both UC and Crohn's disease patients (21). Using fluorescence-activated cellsorter, circulating antibodies reactive against colon epithelial cells from Wistar rats have been reported in patients with UC (22). In contrast to these studies, using CCA-IgG, the $40-\mathrm{kD}$ protein was not detected in the intestinal extracts (both small and large intestines) of two strains of rats, including germ-free rats and mice, suggesting the species specificity of the $40-\mathrm{kD}$ protein. We recently identified intestinal tissue antigens specific for Crohn's disease tissue that reacted with Crohn's disease serum IgG and not with UC serum IgG (23). The molecular weights of these proteins were $160,000,120,000$, and 110,000 and CCA-IgG did not react to any of these proteins present in Crohn's disease tissue (Fig. 5). Whether the specific recognition of the $40-\mathrm{kD}$ protein in human colon extracts by CCA-IgG is related to a bacterial antigens such as $E$. coli and enterobacterial common antigen is unknown. Immunofluorescent studies using $E$. coli and bacteroids grown from feces of normal subjects did not react to CCA-IgG (9). Further studies using purified colonic bacterial proteins are needed to examine the crossreactivity of the $40-\mathrm{kD}$ protein.

Serum and purified serum IgG from patients with symptomatic UC demonstrated antibody-dependent cell-mediated cytotoxicity against a colon cancer cell line RPMI-4788 and not against HeLa cells $(24,25)$. Whether CCA-IgG recognizes the surface protein(s) in the colon cancer cell line and whether it is cytotoxic is unknown. The $40-\mathrm{kD}$ protein detected by CCA-IgG appears to be colon-specific, since extracts of human tissues from ileum, duodenum, stomach, and liver did not react with CCA-IgG. The $40-\mathrm{kD}$ protein is not actin, as it does not react with antiactin. Moreover, though CCA-IgG reacts with the $40-\mathrm{kD}$ protein, it does not react with actin. Serum IgG from patients with symptomatic UC reacted with the 40$\mathrm{kD}$ protein as demonstrated by immunotransblot assay. Serum IgG from patients with active Crohn's disease and control subjects did not react with the $40-\mathrm{kD}$ protein. Using the purified $40-\mathrm{kD}$ protein, further studies are needed to examine whether CCA-IgG and circulating antibodies from different patients with UC are similar, particularly in relation to their antigen specificity.

The fact that 9 of the 10 CCA-IgG and none of the 9 control diseased colon tissue eluted IgG demonstrated immunoreactivity suggests this phenomenon to be unique to UC. Whether this is primary or secondary cannot be completely resolved until the $40-\mathrm{kD}$ protein is further characterized. The presence of the $40-\mathrm{kD}$ protein in UC tissue and in normal colon tissue suggests its possibility to be an "autoantigen" that indeed reacted with the CCA-IgG purified from the autologous colon as well (Fig. 5). However, the role of the $40-\mathrm{kD}$ protein in initiating the disease process, if any, is unknown. Specific autoantibodies against the double-stranded DNA in systemic lupus erythematosus, against thyroglobulin in autoimmune thyroiditis, and against acetylcholine receptor in myasthenia gravis play important roles in the pathogenesis of these diseases (24-26). Many patients who are severely ill have high titers of the specific autoantibodies and monitoring these circulating autoantibodies was extremely helpful in assessing the clinical course (27-30). Future studies using purified $40-\mathrm{kD}$ protein as antigen may enable identification and accurate measurement of CCA-IgG in the circulation, which may help in diagnosis and assessing the clinical activity of the disease.

\section{Acknowledgments}

The authors gratefully acknowledge help from Dr. Richard J. Stockert for the two-dimensional gel experiments; valuable discussions with 
Anatol G. Morell, Srilata Bagchi, Jayanta Roy Chowdhury, Betty Diamond, and Barbara Birshtein; and the excellent secretarial assistance of Anna Caponigro in preparing the manuscript.

This study was supported by research grant NIADDK-AM-21832 from the National Institutes of Health, Bethesda, MD. Dr. Das is the recipient of the Irma T. Hirschl Career Development Award.

\section{References}

1. Broberger, O., and P. Perlmann. 1959. Autoantibodies in human ulcerative colitis. J. Exp. Med. 110:657-674.

2. Kraft, S. C., and J. B. Kirsner. 1980. The immunology of ulcerative colitis and Crohn's disease: clinical and humoral aspects. In Inflammatory Bowel Disease. J. B. Kirsner and R. G. Shorter, editors. Lea \& Febriger, Philadelphia, PA. Second ed. 86-120.

3. Lagercrantz, R., S. Hammarstrom, P. Perlmann, and B. E. Gustafsso. 1966. Immunological studies in ulcerative colitis. III. Incidence of antibodies to colon-antigen in ulcerative colitis and other gastrointestinal disease. Clin. Exp. Immunol. 1:263-276.

4. Perlmann, P., and S. Hammarstrom. 1965. Antigen from colon of germ-free rats and antibodies in human ulcerative colitis. Ann. N. Y. Acad. Sci. 124:377-394.

5. Jewell, D. P., and I. C. M. MacLennan. 1973. Circulating immune complexes in inflammatory bowel disease. Clin. Exp. Immunol. 14:219-226.

6. Gebbers, J. O., and H. F. Otto. 1978. Evidence for local immune complexes in ulcerative colitis. Acta. Gastro-enterol. Belg. 41:329-350.

7. Baklien, K., and P. Brandtzaeg. 1970. Comparative mapping of the local distribution of immunoglobulin-containing cells in ulcerative colitis and Crohn's disease of the colon. Clin. Exp. Immunol. 22:197228.

8. Das, K. M., R. Dubin, and T. Nagai. 1978. Isolation and characterization of colonic tissue-bound antibodies from patients with idiopathic ulcerative colitis. Proc. Natl. Acad. Sci. USA. 75:4528-4532.

9. Nagai, T., and K. M. Das. 1981. Detection of colonic antigen(s) in tissues from ulcerative colitis using purified colitis colon tissuebound IgG (CCA-IgG). Gastroenterology. 81:463-470.

10. Maizel, J. V., Jr. 1971. Polyacrylamide gel electrophoresis of viral proteins. Methods Virol. 5:179-246.

11. Fahey, J. L., and E. W. Terry. 1978. Ion exchange chromatography and gel filtration. In Handbook of Experimental Immunology. D. M. Weir, editor. Blackwell Scientific Publications, Oxford, England. 8.1-8.16.

12. Hudson, L., and F. C. Hay. 1980. Iodination of proteins: iodogen method. In Practical Immunology. Blackwell Scientific Publications, Oxford, England. Second ed. 241.

13. Towbin, H., T. Stachelin, and J. Gordon. 1979. Electrophoretic transfer of proteins from polyacrylamide gels to nitrocellulose sheets: procedures and applications. Proc. Natl. Acad. Sci. USA. 76:43504354.

14. Leaback, D. H., and A. C. Rutter. 1968. Polyacrylamide isoelectric focusing. A new technique for the electrophoresis of proteins. Biochem. Biophys. Res. Commun. 320:477.
15. O'Farrell, P. H. 1975. High resolution two-dimensional electrophoresis of proteins. J. Biol. Chem. 250:4007-4021.

16. Perlmann, P., and O. Broberger. 1963. In vitro studies of ulcerative colitis. II. Cytotoxic action of white blood cell from patients on human fetal colon cells. J. Exp. Med. 117:717-733.

17. Shorter, R. G., K. A. Huizenga, S. G. ReMine, and R. J. Spencer. 1970. Effects of preliminary incubation of lymphocytes with serum on their cytotoxicity for colonic epithelial cells. Gastroenterology. 58:692-698.

18. Thayer, W. R., Jr., M. Brown, M. H. Sangree, J. Katz, and T. Hersh. 1969. Escherichia coli 0:14 and colon hemagglutinating antibodies in inflammatory bowel disease. Gastroenterology. 57:311-318.

19. Zeromski, J., P. Perlmann, R. Lagercrantz, S. Hammarstrom, and B. E. Gustaffson. 1970. Immunological studies in ulcerative colitis. VII. Anti-colon antibodies of different immunoglobulin classes. Clin. Exp. Immunol. 7:469-475.

20. Perlmann, P., S. Hammarstrom, R. Lagercrantz, and D. Cambell. 1967. Autoantibodies to colon in rats and human ulcerative colitis: cross reactivity with E. coli 0:14 antigen. Proc. Natl. Exp. Biol. Med. 125:975-980.

21. Aronson, A. R., L. S. Cook, and K. J. Roche. 1983. Sensitization to epithelial antigens in chronic mucosal inflammatory disease. $J$. Immunol. 131:2796-2804.

22. Hibi, T. B., M. Aiso, M. Ishikawa, M. Watanbe, T. Yoshida, K. Kobayashi, H. Askura, S. Tsuru, and M. Tsuchiya. 1983. Circulating antibodies to the surface antigens on colon epithelial cells in ulcerative colitis. Clin. Exp. Immunol. 54:163-168.

23. Bagchi, S., and K. M. Das. 1984. Detection and partial characterization of Crohn's disease tissue specific protein recognized by Crohn's disease sera. Clin. Exp. Immunol. 55:41-48.

24. Nagai, T., and K. M. Das. 1981. Demonstration of an assay for specific cytolytic antibody in sera from patients with ulcerative colitis. Gastroenterology, 80:1507-1512.

25. Das, K. M., Y. Kadono, and G. M. Fleischner. 1984. Antibodydependent cell-mediated cytotoxicity by sera from patients with ulcerative colitis: relationship to disease activity and response to total colectomy. Am. J. Med. 77:791-796.

26. Morimoto, C., H. Samo, T. Abe, M. Homma, and A. D. Steinberg. 1982. Correlation between clinical activity of systemic lupus erythematosus and the amounts of DNA in DNA/anti-DNA antibody immune complexes. J. Immunol. 219:1960-1965.

27. Abodu, N. I., H. Wall, H. B. Lindsley, J. F. Halsey, and T. Suzuki. 1981. Network theory in autoimmunity in vitro suppression of serum anti-DNA antibody binding to DNA by anti-idiotypic antibody in systemic lupus erythematosus. J. Clin. Invest. 1297:1304-1367.

28. Schechter, Y., R. Maron, D. Elias, and I. R. Cohen. 1982. Antibodies to insulin receptor spontaneously develop as anti-idiotypes in mice immunized with insulin. Science (Wash. DC). 216:542-544.

29. Dwyor, D. S., R. J. Bradley, C. K. Urquhart, and J. F. Kearney. 1983. Naturally occurring anti-idiotypic antibodies in myasthenia gravis patients. Nature (Lond.). 301:611-613.

30. Cleveland, W. L., N. H. Wassermann, R. Sarangarajaw, A. S. Penn, and B. F. Erlanger. 1983. Monoclonal antibodies to the acetylcholine receptor by a normally functioning auto-anti-idiotypic mechanism. Nature (Lond.). 305:56-57. 